\title{
El ícono y su herencia en el arte
}

\author{
DAVID SOLÍs NOVA* \\ Universidad Católica de la Santísima Concepción \\ dsolis@ucsc.cl
}

\begin{abstract}
Resumen
En el siguiente artículo se indaga en torno a la naturaleza del ícono en cuanto tradicional representación pictórica de Cristo y los santos de la Iglesia. Trataremos de entender en qué consiste este arte, cuyos orígenes se pueden rastrear desde los primeros siglos de la cristiandad, cuáles son sus motivaciones, fines y rasgos esenciales, es decir, sobre qué bases ha logrado cumplir un rol tan importante en la vida de innumerables fieles. Por medio de una metodología de revisión bibliográfica y documental, prestaremos atención a las tesis de diversos filósofos, teólogos e historiadores que se han acercado a reconocer y pensar sobre el significado del ícono para el pueblo cristiano. Nuestro propósito es eminentemente filosófico, pero se nutre de muchos autores que se han preocupado, desde diversas disciplinas, por esta especial y conmovedora belleza cristiana. Conocer en profundidad el ícono nos permitirá resolver nuestra pregunta investigativa que apunta a descubrir la herencia que el ícono le entrega al arte universal de todos los tiempos y al arte cristiano en particular. Partimos de la hipótesis de que el ícono encierra un aporte muy original y poco explorado que tal vez pueda ser de gran provecho e inspiración para pensar, por lo pronto, un arte contemporáneo y futuro enriquecido de esta herencia.
\end{abstract}

Palabras claves: ícono, iconografía, arte cristiano, imágenes cristianas, arte.

\section{The icon and its heritage in art}

\begin{abstract}
The following article explores the nature of the icon as traditional pictorial representation of Christ and the saints of the Church. We will try to understand what this art consists of whose origins can be traced from the first centuries of Christianity, what are its motivations, aims and essential features, that is, on what basis has managed to fulfill such an important role in the lives of countless faithful. By means a methodology of bibliographic and documentary review, we will pay attention to the thesis of different philosophers, theologians and historians who have come to recognize and think about the meaning of the icon for the Christian people. Ourpurpose is eminently philosophical, but it is nourished by many authors who have been concerned, from different disciplines, with this special and moving Christian beauty. To know in depth the icon will allow us to solve our investigative question that aims to discover the inheritance that the icon gives to the universal art of all times and to Christian art in particular. We start from the hypothesis that the icon contains a very original and little explored contribution that may be of great benefit and inspiration to think, for now, a contemporary art and future enriched by this heritage.
\end{abstract}

Key words: icon, iconography, Christian art, Christian images, art.

* Doctor en Filosofía por la Universidad Pontificia de Salamanca. Académico de la carrera de Licenciatura en Filosofía de la Universidad Católica de la Santísima Concepción, Chile. Entre sus artículos: "El milagro de san Francisco: la lectura de Max Scheler a la vida del santo de Asís" (2011); "La definición de amor en la filosofía de Max Scheler" (2011); "En el umbral del cristianismo: atención y descreación en la filosofía de Simone Weil" (2016).

Recibido: 3/Junio/2019 - Aceptado: 20/Noviembre/2019 
INTRODUCCIÓN

Hablar de los íconos es hablar de algo más que de una simple experiencia estética. Tal vez esté en juego en ellos la comprensión de lo que podríamos llamar la integridad de la experiencia cristiana. Si bien se pueden indagar los rasgos propios de la iconografía desde las primeras imágenes de la historia cristiana, esta tradición alcanza su mayor fuerza con la paz y aceptación oficial de la Iglesia de Cristo, que trae la conversión del emperador Constantino. Poco a poco van consolidándose las imágenes principales, por ejemplo, la de Cristo, siendo inicialmente representado por medio de símbolos (Orfeo en los infiernos, Hermes como buen pastor); pasando luego por la figura del joven pastor imberbe, con pelo rizado y descalzo; hasta llegar en el siglo $\mathrm{V}$ al personaje barbudo, con pelo largo, con aspecto majestuoso, severo y melancólico. Este modelo prevalece en oriente a partir del siglo VI y evoluciona hasta el Pantocrátor del arte bizantino. Lo mismo sucede con la imagen de la Madre de Dios (Theotokos), la de los santos y las escenas sagradas, que van encontrando paulatinamente los cánones en los que son popularizados y, a la vez, aceptados por la Iglesia. Los íconos tienen en el siglo VI y VII una enorme difusión. Los encontramos presidiendo los juegos del hipódromo, marchando al frente de los ejércitos y ganando batallas con su sola presencia. Las imágenes sagradas llegan a tener una presencia notable en todos los aspectos de la vida cotidiana, convirtiéndose en factor importante de la vida individual, familiar y ciudadana (Besançon, 2003: 142; Belting, 2009: 12). Es, sobre todo, en Bizancio donde los íconos llegan a adquirir esa notable función de intermediarios, entre el fiel y la comunión de los santos. Luego de la victoria sobre los iconoclastas, esta postura se hace aún más marcada, llegando todavía hasta nuestra época su espíritu, fulgor y serenidad, sobre todo en los países con mayor presencia de la Iglesia ortodoxa, aunque no solamente en ellos.

Nuestro objetivo en este artículo es poder conocer la naturaleza del arte icónico y, a partir de ello, comprender la herencia que ha dejado para la historia de las imágenes y, sobre todo, para la experiencia artística. Creemos que conociendo mejor esta herencia sería posible que el arte pudiese aprovecharla de una manera más intensa y conciente. Algunos de sus rasgos distintivos tienen una notable profundidad y enriquecen aún más lo que comúnmente entendemos por arte o experiencia estética. Si bien el ícono nace y tiene su pleno sentido dentro del seno de la vida eclesial, indagar en sus características esenciales ensancharía el horizonte de todo pensamiento interesado por el misterio que encierra la belleza. Este tema nos interesa también para comenzar y propiciar una reflexión sobre qué entendemos por arte cristiano, cuáles son las condiciones en las que podría 
surgir y si es posible en nuestra época un arte de ese tipo; al menos, iniciar a vislumbrar algunos caminos de solución sobre este último punto. Utilizamos en este estudio una metodología bibliográfica documental con la cuál revisamos una serie de autores pertenecientes a diferentes disciplinas del saber como la filosofía, la teología y la historia, pero nuestro interés es poder responder una inquietud propiamente filosófica en torno a todo el significado de vida y experiencia humana que encierran estas entrañables imágenes cristianas y lo que podríamos llamar su singular pensamiento propulsor o pensamiento icónico.

\section{1. ÍCONO E ÍDOLO}

Sería difícil hablar del ícono sin mencionar la fuerte querella iconoclasta que conmovió el imperio bizantino entre los siglos VIII y IX. Aunque algunas ideas de rechazo al ícono ya se habían hecho notar en los textos de Eusebio de Cesarea y Epifanio de Salamina, no fue hasta la llegada al poder del emperador León III, el isáurico, cuando se prohibieron los íconos y su veneración. Estalla la disputa cuando el emperador ordena quitar la imagen de Cristo de la puerta de bronce del palacio imperial (año 726). El movimiento liderado por el emperador fue reafirmado por un concilio iconoclasta en el año 754, donde participaron más de trescientos obispos. El impulso continuó con el régimen del sucesor de León, Constantino $\mathrm{V}$, quien no sólo poseía habilidades de estratega militar, sino que también estaba dotado de buenos argumentos teológicos para reafirmar la postura iconoclasta.

Los especialistas revelan variadas causas posibles del origen de la querella, por ejemplo, el abuso supersticioso que se estaba haciendo del ícono que encendió el celo de algunos teólogos y obispos, ya que inevitablemente les recordaba el culto pagano de los ídolos. Se plantean también razones de orden político en función de aumentar la influencia del poder central de Constantinopla (Belting, 2009: 17; Besançon, 2003: 147). También se apunta al origen sirio del emperador, lo que lo habría expuesto a la influencia del monofisismo y el Islam, que finalmente habría dejado en él un desprecio por las pretensiones de las imágenes sagradas (Besançon, 2003: 147; Schorborn, 1999: 137-138). También se menciona la imagen que León III habría tenido de sí mismo, la imagen de un gran reformador, un rey-sacerdote llamado por Dios a purificar su iglesia de la idolatría y reconducirla a su estado original, recogiendo, en este caso, la prohibición veterotestamentaria de no construir ídolos ni imágenes de Dios (Grabar, 1998: 155; Schorborn, 1999: 139-140).

La argumentación de ambos emperadores como la del concilio iconoclasta, podría sintetizarse en la idea de que es imposible que la 'materia 
indigna' pueda circunscribir al inconcebible Hijo de Dios. La Eucaristía aparece a sus ojos como la única 'imagen' válida de Cristo y la cruz como el símbolo por antonomasia que remite a su obra redentora. Las ideas fundantes que están detrás de la iconoclasia son las de una abrumadora trascendencia divina y las nociones 'platonizantes' que menosprecian el 'apego a la tierra y a los sentidos' que encerraría la veneración de las imágenes sagradas.

La querella produjo luchas cruentas y muchos mártires hasta que la emperatriz Teodora, en el año 843, mandó a restaurar y reponer la imagen de Cristo en la puerta del palacio imperial, destruida por León III. La lucha duró unos 120 años aproximadamente, pero no sólo generó conflictos sino una amplia gama de argumentos filosóficos y teológicos, sobre todo entre los defensores del ícono (san Germán, el patriarca Nicéforo, Juan Damasceno, Teodoro el estudita, entre otros), algunos de los cuales retomamos y prolongamos ahora.

$\mathrm{Al}$ venerar al ícono veneramos a la persona representada en él. El honor rendido al ícono va en dirección al santo que se ha pintado en sus caracteres singulares y únicos, es decir, el honor entregado al ícono va a su prototipo. Podríamos decir que toda la gloria del ícono es poder reenviar la mirada del fiel hacia la gloria del santo representado. El ícono no se ubica en primer lugar para que lo visto sea la gloria de la persona santa. Es más bien el mediador para el encuentro entre el pueblo cristiano y los santos bienaventurados. Si el ícono acaparara para sí toda la visibilidad, por medio de una originalidad de vanguardia o un gran virtuosismo, terminaría impidiendo este encuentro, ya que la mirada quedaría detenida en su misma perfección. Ante una pintura de Rafael exclamamos: 'UUn Rafael!', pero ante un ícono nos arrodillamos o persignamos porque nos percibimos vistos por el santo. En las capillas decoradas por Matisse o Cocteau, terminamos viendo más el talento de los grandes artistas que a Cristo y sus santos. Provocan más nuestra admiración que un encuentro personal con el santo representado. El ícono, más que ser visto, lo que busca es que seamos vistos. El ícono no se deja ver para dejar ver (Marion, 2006: 112). ¿Dónde encontrar una imagen que se deshaga de su propia visibilidad para dejar en evidencia otra mirada? (Jn 3,30): En la humildad de Cristo que acepta que dañen su propia figura - hasta perder la apariencia humana (Is $52,14)$ - para hacer visible a través de él la voluntad del Padre. Aunque Él es la belleza misma, se deja escupir y desfigurar el rostro, convirtiéndose Cristo en el primerísimo ícono, el ícono de Dios (2 Corintios 4, 4).

Injustas son las comparaciones que quieren acercar el ícono al ídolo. El ídolo es la mera concentración de los deseos del sujeto y nos devuelve sólo lo que nosotros hemos puesto anteriormente en él. Si alguna vez llega a dominarnos, es porque nosotros mismos lo hemos permitido debido a 
que es completamente creación nuestra. Bajo la influencia del ídolo no salimos de nosotros mismos, de nuestras ideas preconcebidas y frustraciones: el ídolo es sumiso y solipsista. Es, en síntesis, la adoración orgullosa de nuestras propias obras (Beuchot, 1999: 63). Es todo lo contrario del ícono que es siempre el encuentro con un otro distinto y, como todo encuentro, es siempre imprevisto e impredecible. La mirada que viene de la pintura icónica enfrenta nuestra propia mirada, la interroga, la conmueve y, en ocasiones, la derriba. Ante el cruce de miradas, nadie puede predecir qué acontecerá. Además, es también injusta la acusación de idolatría que se hizo recaer sobre el pueblo cristiano por honrar los íconos, ya que en ningún caso se considera que la imagen sea el mismo Dios, sino sólo una semejanza pintada. El ícono no es sagrado, es solamente venerable por ser el 'representante' del bienaventurado. Ya Juan Damasceno había enseñado que las imágenes eran dignas de veneración (proskinesis) y no de adoración (latreia). La adoración sólo debe ir dirigida al mismo Dios que, para nosotros, se encuentra presente en la eucaristía en su cuerpo y sangre. Pero el ícono nunca ha querido para sí esta adoración y sólo ha querido ser el propiciador del encuentro del pueblo orante con la gloria de los santos (Schorborn, 1999: 200). Gracias a su semejanza sensible con la persona santa, el ícono hace más fácil al cristiano dirigir su mirada hacia el Reino de Dios, pedir que tal Reino venga y entre en su vida y en sus preocupaciones. No conmemora a hombres del pasado, sino que es la memoria viva de hombres contemporáneos (Gombrich, 2014: 106-107; Nagel \& Wood, 2017: 32-33) : "El ícono es un eslabón entre encarnación y Parusía, entre la primera y la última venida del Señor" (Schorborn, 1999: 135). Podríamos decir que la oración ante el ícono es el inicio en nuestro presente de la comunión de los santos.

No se trata sólo de contemplar el ícono, sino de co-instituir con él una relación. No es casualidad que los rostros de las imágenes icónicas, en la mayoría de los casos, miren de frente. Es más, podríamos decir que estas imágenes están organizadas alrededor de las miradas de los santos, lo que permite que la presencia de estos nos aborde (Nancy, 2012: 18). Son miradas que buscan la mirada del fiel para interpelarlo. Como sostiene Levinas: "El rostro, aún cosa entre cosas, perfora la forma que, sin embargo, lo delimita. Lo que quiere decir concretamente: el rostro me habla y por ello me invita a una relación sin paralelo" (2002: 211). Esta interpelación no limita necesariamente mi libertad, sino que la promueve y la incita. Al suscitar mi imputabilidad y responsabilidad, promueve mi libertad. Al dejarme interpelar, generar y transfigurar por el estado interior de oración del santo, le estoy dando verdadero origen y sentido a mi libertad (Levinas, 2000: 214). El ícono pareciera decirnos que su rasgo más distintivo es su modo de ponerse en relación con otros, que no es nada si no es puesto en 
relación, al igual que la persona de la cual es semejanza: su cualidad más íntima es el modo respectivo de ponerse en relación con otras, tener en los otros el propio origen. Tanto para el ícono como para las personas la plena entrega equivale a la posesión perfecta de sí mismo.

Frente al ícono no somos simples mirones (Damisch, 1997: 127), podemos cruzar la mirada con otro ser humano: es el trabajo compartido de las miradas tanto del fiel como del ícono (Marion, 2006: 111). Una mirada que no cansa porque no está fijada, presupuesta, es constantemente reiniciada. Por ejemplo, Belting describe una serie de íconos donde se produce un cruce de miradas tal que el santo representado puede dirigirse al fiel y al mismo tiempo abogar ante Dios por la petición del orante bajo su amparo. De alguna manera el orante se integra al movimiento del diálogo emergente e incesante- entre María, abogada nuestra, y el Señor (Belting, 2009: 486). El encuentro, que es lo que caracteriza a todo el cristianismo, es propiciado una y otra vez por medio de las imágenes sagradas: "El hombre delante del ícono es como el ángel delante de la luz divina" (Grabar, 1998: 219). En el ícono es importante no sólo lo que podemos ver sino también la medida en que podemos llegar a ser vistos. O, más aún, poder superar la simple categoría de ver y ser visto y ahondar en la experiencia de un encuentro y una convivencia con la comunión de los santos. Cuando rezamos, no analizamos el ícono como a un objeto de estudio, es, más bien, el santo mismo quien, por medio del ícono, nos enseña.

\section{EL ICONÓGRAFO Y SUS FUENTES}

Por todo lo anterior, se suele señalar que no podría pintar un ícono quien no tiene la experiencia del encuentro con Cristo y su Iglesia. En efecto ¿Cómo podría pintar las semejanzas de los santos bienaventurados quien no ha saboreado un poco de esa bienaventuranza? ¿Cómo podría representar las señales de la comunión con Cristo quien no ha recibido los beneficios de esa amistad? ¿Cómo podría pintar el ícono de Cristo quien no conoce el modelo vivo? Sin el conocimiento de Cristo, la pintura de iconos sería sólo producto de la imaginación y de las especiales dotes del pintor. Por ello Florenski puede afirmar con tanta naturalidad: "Existe la Trinidad de Rubliev, luego Dios existe" (2016: 76), ya que este ícono sólo podría haber sido pintado gracias a una auténtica experiencia trinitaria, es decir, no pudo haber sido fruto sólo de una idea brillante, sino que necesariamente debe ser fruto de una experiencia de vida.

El encuentro sólo se puede conocer dentro del encuentro. No se lo podría conocer desde una perspectiva exterior, que inevitablemente llegaría a ser una perspectiva ajena. Para conocer el encuentro es necesario ingresar a él, de otra manera nunca llegaremos a su verdadero y viviente 
'contenido': "No puedo situarme realmente fuera de él ni frente a él, estoy comprometido en este encuentro, dependo de él, le soy, en cierto modo interior; me envuelve y me abarca aunque yo no lo abarque a él" (Marcel, 1987: 43). Por eso se señalaba en la tradición de los pintores de íconos que los verdaderos iconógrafos eran los santos padres, ya que en ellos va quedando la imagen verdadera de Cristo. Nosotros podríamos agregar que la imagen verdadera de Cristo va quedando en todo el pueblo cristiano y es en esta cadena ininterrumpida de testigos donde los iconógrafos encuentran la fuente original de su trabajo: "La materia, por así decirlo, en que trabaja y crea el santo no es madera, piedra y color, sino la persona del hombre mismo y, por consiguiente, de todos los hombres posibles" (Scheler, 2000: 286). Cristo no ha llegado a nosotros principalmente en libros, conceptos y reliquias, sino en el pueblo cristiano donde hemos visto resplandecer su imagen (2 Cor 3,18). A diferencia de lo que pasaría después con los pintores modernos de motivos religiosos, los iconógrafos -los pintores de imágenes sagradas- debían ser miembros de la Iglesia, pues su talento era un servicio a esta y, finalmente, un camino tan válido como otros para alcanzar la santidad. Además, un error en el ícono podría perjudicar la fe de innumerables fieles, por lo mismo, era imprescindible que fueran buenos cristianos. En su pintura no sólo ayudaban a hacer aparecer el ícono de Cristo, sino que también ayudaban a dibujar la imagen y semejanza de Dios en sus propias vidas. La pintura de íconos es una oración con los pinceles y un camino de salvación.

\section{EL ÍCONO COMO TRABAJO COMPUESTO}

Este encuentro que propicia el ícono no se produce de una vez para siempre, sino que debe reanudarse una y otra vez. La experiencia de la encarnación de Cristo debe volver a recomenzar con inicios siempre nuevos, ya que no es un mero 'recuerdo', sino la reanudación de un suceso contemporáneo: "El ícono...no es una experiencia imaginativa de un acontecimiento pasado... sino reactualización de la vida de Cristo en la liturgia de la Iglesia" (Gombrich, 2014: 125). Sin embargo, esta experiencia es un trabajo compuesto entre el santo y el fiel, ya que el encuentro no es automático. Requiere del acontecimiento de la Gracia, pero también de la actitud de espera y la disponibilidad del orante. Sin este pequeño material, nuestro consentimiento, la Gracia no tiene donde asirse, no tiene cómo trabajar. El ícono es puesto en movimiento por alguien que viene, pero también por alguien que lo deja acontecer: "La relación significa elegir y ser elegido" (Buber, 2013: 13). Sin esta synergia fracasa el encuentro. El fracaso de la espera del hombre, es el fracaso del acontecer de Dios: "Yo estoy a la puerta y llamo: si alguno abre la puerta entraré y cenaré con él" 
(Ap 3, 20). Porque tiene nuestro consentimiento puede entregarnos su herencia de bienaventuranza: "El Logos debe poseer aquello que es nuestro para darnos lo que es suyo" (Schorborn, 1999: 80). El ícono es una muestra más del admirabile commercium entre Dios y el hombre, un hombre que gana su bienaventuranza -retornando a su imagen y semejanza divina-, un Dios que gana en su encarnación adquiriendo su propia humanidad y la amistad del hombre. Tal como lo señala Evdokimov, inspirado en san Atanasio y Clemente de Alejandría, "La creación del hombre a imagen de Dios tenía como fin la encarnación...Dios ha creado el mundo para hacerse hombre en él...La encarnación viene de Dios, de su deseo de hacerse hombre" (1991: 51 y 195). En este encuentro el hombre gana, pero Dios también gana en su posibilidad de entrar en una comunión siempre renovada e impredecible con los hombres gracias a su encarnación: gana amigos, una madre, un padre nutricio, un cuerpo, una historia de hombre. Sin encarnación no se hubiese producido esta sinergia, este trabajo compuesto, que nos permite llamarlo amigo y Padre, y hubiese quedado en 'solamente Dios', Dieu seulment (Péguy, 1992: 726), inmenso, infinito, pero sin mayor incidencia en la historia de los hombres.

\section{4. ÍCONO Y TRANSFIGURACIÓN}

Se sostiene en ocasiones que el ícono manifiesta una falta de realismo en la representación del hombre, de la naturaleza y la arquitectura. No pareciera que los pintores de íconos quisieran pintar las cosas tal como las ven nuestros ojos e, incluso, pareciera que buscaran ya derechamente una 'desrealización' o 'desmaterialización'. Creemos que estas afirmaciones son, por lo menos, poco exactas y que deben desarrollarse mucho más. Por nuestra parte consideramos, más bien, que la extraña apariencia que presentan los íconos a los ojos modernos - las alargadas figuras de los cuerpos, las pequeñas cabezas de los santos, los inusitados colores de las vestimentas y las cubiertas de las escrituras, la libertad en la configuración de los rostros y la arquitectura, etc.- no son primeramente un intento de 'desmaterialización', sino, muy por el contrario, de acercarse de una manera más radicalmente fiel a la experiencia (Gombrich, 1997: 146). En el ícono hay un deseo de pintar la experiencia humana tal y como se la percibe, pero la diferencia se encuentra en que el iconógrafo está pintando una realidad que es siempre en relación, un mundo que está transfigurado por el encuentro con Cristo (Evdokimov, 1991: 33-34; véase 'La Transfiguración' de Teófanes el griego, en el siglo XIV). Sostenemos, en definitiva, que en el ícono hay tanta verdad como en una pintura que más fácilmente nuestros ojos contemporáneos calificarían como 'realista'. Por ejemplo, en los dibujos de un niño aparece su padre o su madre siendo 
más grande que una montaña (Gombrich, 1997: 106). Alguien diría que su dibujo tiene errores graves de perspectiva y de conocimiento de las dimensiones de la realidad. Sin embargo, el infante insiste con ese tipo de dibujos porque, en su percepción, su padre o su madre son más significativos que cualquier montaña, es decir, son 'realmente', dentro de la relación padrehijo, más grandes que la montaña (Gombrich, 2014: 115). El niño no está pintando la realidad neutramente o, nos atreveríamos a decir, abstractamente, desde una altura impersonal, sino que está pintando el mundo tal como siempre lo percibimos (Panofsky, 2003: 13), es decir, un mundo en relación, un mundo lleno de significaciones y traspasado por las relaciones que he compuesto con otros. No podríamos ver un mundo si alguien no nos lo hubiera mostrado y no podríamos seguir viendo un mundo sino dentro de las relaciones humanas que generamos permanentemente. El mundo aparece, incluso en su 'objetividad', a través de un 'tú'. Por ello, para ese niño, que dibuja lo que efectivamente ve, sus padres son inmensamente grandes, más que una casa y un árbol, porque son ellos los que, no sólo lo han traído al mundo, sino que lo traen al mundo una y otra vez, al mostrárselo lleno de la significación de su afecto y cuidado.

De la misma manera creemos que el ícono pinta la realidad con el mismo espíritu de respeto por lo que efectivamente percibimos. En este caso, la realidad que pintan son la vida de los santos del Reino de Dios, la realidad que está ya transfigurada por el encuentro con Cristo, es decir, la materia dentro de una relación Padre-hijo. Se pinta todo el mundo en esta relación y no se busca el punto de vista neutral y absoluto de un ojo impersonal, sin ligazón ni amistad con nadie. El pintor no está pintando ni una pre ni una post historia, sino una historia contemporánea de salvación, la historia de los amigos de Jesús (Belting, 2009: 352). El hombre y la naturaleza que pinta el ícono no es una representación forzosamente rejuvenecida ni ansiosa de perfectismo, sino un hombre y una naturaleza redimida del pecado, en su estado de inocencia, es decir, en el pleno restablecimiento de la Alianza con Dios. Hombre, naturaleza y objetos son transfigurados por este nuevo acontecimiento. El intento de representar pictóricamente este acontecimiento da como fruto el ícono (véase 'El Bautismo de Cristo' del museo bizantino de Atenas o 'La natividad' de la escuela de Navgorov en Moscú).

Todo el cuerpo manifiesta esta transfiguración. Por ello, no debe extrañarnos tanto los nimbos que iluminan los rostros de los santos en el ícono porque, al igual que san Esteban (Hch 6, 15), sus rostros parecen resplandecer como el de los ángeles por la alegría de caminar con el Señor. Tal como sostiene Florenski: "El cristiano habla con su propio cuerpo" (2016: 61), todo su cuerpo enseña y muestra esta relación y transfiguración. El santo ayuda, además, a transfigurar a otros, no sólo con lo que dice, 
sino también con lo que es. Y lo que él es remite al rostro de un otro que ha renovado su vida: "La cualidad más íntima de las personas no es otro que el modo respectivo de ponerse en relación con otros" (Schorborn, 1999: 35). Hasta la misma vestimenta de los santos que vemos en los íconos nos habla porque su objetivo no es ocultar el cuerpo sino evidenciarlo de una manera más personal. La desnudez, en ocasiones, puede mostrar de un modo borroso al hombre, en el sentido de poco singularizado, todavía demasiado genérico. La vestimenta le sirve al iconógrafo para profundizar en la noción de que el cuerpo del hombre no es pura biología, sino un cuerpo lleno de pensamiento, un cuerpo en una amistad, un cuerpo personal. Creemos que la belleza y sencillez de la vestimenta icónica se debe, más que a una búsqueda de un resplandor elegante, a la concepción de que la vestimenta es la continuación de un cuerpo redimido, de un cuerpo que no es pura carne, sino un cuerpo pletórico del pensamiento de Cristo (1 Cor 2,16). La vestimenta es una muestra de la sobrenaturaleza del cuerpo, al igual que el mundo humano no es un mundo salvaje, sino una naturaleza permanentemente transformada en el Reino de Dios, en una sobrenaturaleza forjada dentro de una comunión (véase El ícono 'Cristo y el abad Mena', siglo VI aproximadamente).

En todo lo que hemos señalado no intentamos de manera alguna mostrar que el ícono sea una especie de superación de la percepción sensible o la búsqueda de una aprehensión de supra-realidades más puras o más espirituales. Señalamos, más bien, que el ícono intenta mostrar lo que siempre sucede, esto es, el carácter comunional de nuestra percepción (Damisch, 1997: 46). Nuestros sentidos también se ven transfigurados por la relación, no son sentidos puros, sino sentidos llenos de significado (Brown, 1998: 105ss.; Gombrich, 2014: 63-76-251-331). La comida y el vino tienen un sabor diferente si son compartidos con los amigos. La agudeza del oído de una madre es diferente si sabe que su hijo está enfermo y debe estar atenta a su llamado. La conversión del cristiano no es sólo de su pensamiento, sino de todo su ser, incluidos los sentidos. Por algo en la contemporaneidad de la eucaristía se exhorta a los sentidos a participar: el gusto en la comunión, la vista en los venerables íconos, el oído en la música litúrgica, el olfato para reconocer el incienso. Los sentidos son invitados a esta redención, a esta transfiguración por la vía de la recomposición de la amistad con Dios. Creemos, con von Balthasar, que es necesario reconocer esta realidad de los sentidos cristianos: Son los mismos sentidos, pero intensificados por la nueva experiencia de ser configurados según la forma de Cristo (von Balthasar, 1985: 374).

De acuerdo a lo anterior, todo lo que rodea al santo en el ícono está transfigurado. La naturaleza misma espera su transfiguración, en medio de 
dolores de parto (Rom 8, 18-25), por medio del hombre y su trabajo redimido: "La naturaleza espera gimiendo que su belleza sea salvada a través del hombre hecho santo" (Evdokimov, 1991: 45). Las imágenes del ícono muestran una naturaleza que ya no causa terror ni angustia al hombre, sino una que colabora en su oración. La naturaleza presente en el ícono también ha derrotado a la muerte y participa de la bienaventuranza de la comunión de los santos (Uspenski, 2013: 196).

El espacio y el tiempo adquieren también un nuevo sentido. Vemos escenas que ya no pueden suceder en el interior de una construcción porque el acontecimiento que muestran pareciera no poder encerrase en cuatro paredes. Por eso las escenas de la iconografía suceden ante los edificios y no en el encierro de una construcción. El espacio parece pequeño en relación al hombre porque los frutos de ese acontecimiento no son sólo para unos pocos, sino para todos los hombres, para toda la ciudad, para todo el cosmos y para toda la historia. Porque pertenecen a la historia de la salvación que es también un tiempo transfigurado. Es un tiempo de una cualidad diferente porque es tiempo en relación. La eternidad del ícono, en este sentido, no es ausencia de tiempo, sino tiempo en plenitud, tiempo en relación y lleno de la novedad de la amistad con Cristo (véase El ícono 'Pentecostés' del siglo XV de la escuela de Moscú). La comunicación entre los santos hace nuevas todas las cosas, incluyendo el espacio y el tiempo: "La plegaria no tiene existencia en el tiempo sino el tiempo en la plegaria...el sacrificio no tiene existencia en el espacio, sino el espacio en el sacrificio" (Buber, 2013: 11-12). En este mismo sentido, la existencia cristiana no sucede en el tiempo y en el espacio, sino más bien el tiempo y el espacio adquieren un nuevo sentido dentro de la experiencia cristiana. La amistad recompuesta con el Padre rejuvenece al mismo espacio y al tiempo. Hacia este punto quiere dirigir la mirada la iconografía. Por ello, no debe extrañarnos encontrar a un san Basilio más grande que una ciudad (Uspenski, 2013: 193) o puertas demasiado pequeñas para que el cuerpo de los santos pueda entrar (Uspenski, 2013: 196-197) o un san Pedro con una mano que bendice al pueblo tan grande como su cabeza (Grabar, 1998: 360) o el rostro frontal de Cristo que se nos presenta en todos sus ángulos al mismo tiempo y en un solo plano (Florenski, 2005: 27). El ícono no es 'desmaterialización', sino materia transfigurada: lo que muestra es la verdadera imagen del hombre en cuanto ícono viviente de Dios.

\section{5. ÍCONO Y TRADICIÓN}

Como señalábamos anteriormente, el iconógrafo no pinta para que su talento individual resalte como lo primero en ser visible. Su talento principal consiste en dejar ver un rostro y no una simple pintura. Su virtud 
como iconógrafo radica en presentar una persona, no en crearla, para que, finalmente, la oración se dirija a una persona de la cual el ícono es un medio de comunicación, un tipo que remite a su prototipo. Para ello, el pintor de íconos trabaja sobre una serie de formas canónicas e indicaciones transmitidas por tradición, las que no son vistas como obstáculos para la creatividad ni limitaciones a la libertad de su trabajo (Gombrich, 2014: 248). Así como nadie consideraría que tener que usar un idioma determinado es una limitación para la libertad del pensamiento y la expresión, el iconógrafo considera que el piso y fundamento que entrega la herencia de la tradición es una ayuda y no un obstáculo para manifestar su libertad. No es justo sostener que los iconógrafos no pudieron manifestar talento y maestría ni que la tradición es una simple momificación del pasado: "Este conservadurismo sólo se desarrolló gradualmente y es equivocado imaginar que los artistas de esa época no fueran capaces de otros logros. Fueron ellos, en efecto, los que transformaron las simples ilustraciones del arte cristiano primitivo en grandes ciclos de enormes y solemnes imágenes que dominan el interior de las iglesias bizantinas" (Gombrich, 1997: 109). De hecho, respetando estas formas canónicas, mientras la tradición del ícono se mantuvo viva, se dio una gran diversidad de escuelas iconográficas que no sólo representaban las singularidades de ciertas épocas, sino de ciertos pueblos, culturas y, dentro de ellas, de escuelas inspiradas por determinados santos (Gombrich, 1997: 122-123). En el mismo sentido, respetando el mismo credo, hemos visto florecer en la cristiandad una diversidad inmensa de santos, con caracteres, historias y obras tan distintas, que nos lleva a pensar que no hay nada más singular que la personalísima vida de los santos bienaventurados. Sin embargo, tras ellos está el mismo Cristo. Si alguien descubre monotonía en el ícono, esta no se debe a las formas canónicas, sino a la experiencia cristiana que decrece, transformando al ícono solamente en una producción masiva de imágenes devocionales. Si el dogma parece una cárcel es porque la fe ya no está viva.

El respeto a estos cánones no es signo de sumisión irreflexiva, es fruto del juicio libre del cristiano que entiende que la historia de la inteligencia de la fe y de la Iglesia ha sido trabajada por muchas generaciones anteriores que han intentado ser testigos verídicos de Cristo. El iconógrafo, por lo tanto, no quiere a toda costa que la obra que realiza sea suya —en el sentido de individual, distinta y originalísima - sino que sea verdadera, es decir, que respete la tradición de los padres de la Iglesia, los apóstoles y la Iglesia toda que nos ha mostrado la persona del Salvador. Agregamos en este punto que no entendemos tradición como el intento de momificar y conservar, sin mayores argumentos, el pasado. Esto es lo que pretende el conservadurismo injustamente asimilado a tradición: el conservadurismo es la tradición sin vitalidad, resistiéndose simplemente a morir. Tradición viva 
es el testimonio y experiencia del pasado que se vivifica y actualiza en el presente. El iconógrafo respetando esta tradición, la actualiza y rejuvenece en la elaboración de cada ícono. El pintor de íconos no se siente como un artista que trae una mirada nueva a la historia de la pintura, sino como un obrero más de la tradición. En expresión de Guardini: "El hombre que crea una imagen de culto no es un 'artista' en nuestro sentido. No 'crea', si tomamos esta palabra tal como solemos usarla, sino que sirve" (Guardini, 1960: 23; Gombrich, 2014: 125). La experiencia cristiana es una experiencia eclesial, por ello mismo el trabajo del iconógrafo se realiza en comunidad. Muy raramente los íconos son firmados porque se entiende como una obra colectiva y universal de la Iglesia (Gombrich, 1997: 152153). Y aunque un ícono hubiese sido pintado por un solo pintor, esta obra supone toda la tradición anterior, de igual manera como una eucaristía celebrada por un solo sacerdote supone toda la tradición eclesial: "En estas formas, no se aprecia únicamente el genio de un artista, sino el alma de un pueblo" (Juan Pablo II, 1999: 8), en este caso el pueblo cristiano.

El ícono es una obra universal porque todos pueden comprenderlo. El ícono es simple porque quiere llegar a todos, quiere ser efectivamente católico. 'Simple' no es lo 'poco inteligente' o de mal gusto. Lo simple hace lo más difícil: generar el encuentro que cambia la vida para que pueda ser corroborado en todos los estratos sociales y culturales. El ícono es, en su estricto sentido, popular: tiene la vocación de entrar en cada aldea, en cada casa, en cada capilla, en cada circunstancia económica y educacional (Gombrich, 1997: 106). Es un auténtico unificador del pueblo. Ante él inclina su rodilla el aristócrata y el analfabeto. La sencillez universal del ícono encuentra su paralelo en los evangelios. Los textos sagrados, llenos de sabiduría y relatando los sucesos cruciales de la historia, son expresados en un lenguaje llano, claro y sobrio, para que puedan ser alimento vital en todas las experiencias humanas. Las palabras de la salvación son las más sencillas: padre, hijo, pan, vino, semilla, esposa, esposo, etc. Una poesía demasiado intrincada o intelectualizada haría difícil de comprender la buena nueva, sería una salvación dirigida solo a un cierto sector de la población. Si Mallarmé o Lautreamont hubiesen escrito los evangelios, estos hubiesen quedado restringidos a los pocos ilustrados que pudiesen entender este lenguaje. Sería una gnóstica salvación para especialistas. El ícono también busca esta sencillez, léase universalidad, tratando de alcanzar con el mínimo de detalles el máximo de expresión. El ícono es testimonio al igual que los evangelios: el ícono es al sentido de la vista lo que los evangelios son a la audición, y su sencillez deja traslucir la teología más profunda. En el caso del ícono, podríamos decir que su apreciación estética no se separa de su apreciación teológica, es más, como hijo de la tradición, 
podríamos señalar que el ícono es teología en colores, una teología traducida a una belleza sensible.

\section{6. ÍCONO Y PERSPECTIVA}

En comparación con la pintura occidental posterior al Renacimiento, el ícono no se compone de acuerdo a la perspectiva lineal. Entendemos por 'perspectiva lineal' aquella en que se estructura todo el cuadro de tal manera que todas las líneas del dibujo confluyen en un solo punto en el horizonte (punto de fuga), al fondo del cuadro (Panofsky, 2003: 12). Las líneas se encuentran en el horizonte, haciendo que los objetos sean más pequeños de acuerdo a su lejanía respecto del observador. Esta pintura nos muestra un punto de vista, un ángulo de visión, "líneas dirigidas por el ojo hacia un centro" (Berenson, 1944: 91; Damisch, 1997:17). Esto es coherente con el propósito de la pintura surgida poco a poco desde el Renacimiento, donde lo que se intenta mostrar es, más que el trabajo de una tradición, el punto de vista o el particular ángulo de visión de un artista (Gombrich, 1997:150-151). Tomamos, obviamente, los resguardos de que esto acaeció paulatinamente y no de un modo uniforme (Damisch, 1997: 32-41; Nagel \& Wood, 2017: 16-27). El artista nos presta, por decirlo así, su mirada, su especial punto de vista, el asombroso y bello ángulo que ha logrado atrapar de la inmensa e impredecible realidad. Ese asombro especial que ha capturado su mirada es el que el artista quiere comunicar, aunque siempre es su mirada (Gombrich, 2014: 15-275-276-304). En el lienzo moderno - plástico, flexible, dúctil- el artista plasma su especial descubrimiento, su original ángulo de visión y pensamiento. Se suele sostener, en cambio, que el ícono manifiesta una perspectiva invertida y no lineal (Florensky, 2005). Las líneas del cuadro no se encuentran en el horizonte, sino que confluyen hacia el espectador. Las imágenes del ícono, más bien, llegan, se acercan al espectador, acontecen ante él y lo encaran. Las líneas dan la impresión de que los personajes van a su encuentro. En este sentido el ícono no nos entrega una perspectiva individual y personal del santo, una originalísima meditación sobre su vida, sino que quieren ser instancia de que el santo se acerque, que venga tal como él quiera acontecer. En este sentido, no necesariamente lo más alejado debe ser más pequeño.

Sin negar la justeza de las apreciaciones anteriores, consideramos que para comprender integralmente al ícono, no sólo como el fruto de una época de la historia del arte sino también como una experiencia cristiana, debemos ir un poco más allá de un análisis de las nociones de perspectiva, ya sea lineal o invertida. Así como el encuentro con una persona no podríamos reducirlo a un intercambio de miradas o puntos de vista, de igual 
manera el ícono es más que un ángulo de visión o una impresión perspectivista, aunque sea invertida. El ícono, en cuanto instancia de encuentro entre personas, incluye las perspectivas, pero las supera, ya que, como decíamos, es más que un espectáculo, es un medio que genera comunión. La fijación de la mirada es antinatural en un encuentro ${ }^{1}$. Si nos mantenemos en puras perspectivas, nunca accedemos a la persona, como sostenía ya Bergson: "Símbolos y puntos de vista me colocan, pues, fuera de ella; no me dan de ella sino lo que es común con otras y no le pertenece exclusivamente. Sólo la coincidencia con la persona me daría lo absoluto" (Bergson, 1969: 99). El ícono no es sólo objeto de visión, es sujeto. El ícono com-pone con nosotros una relación con inicios siempre nuevos. El ícono es instancia de trabajo compuesto entre el santo que debe acercarse, que debe tomar iniciativa, y el fiel que debe mostrar esta disponibilidad para el encuentro y enriquecer su experiencia. Ambos deben trabajar para mantener esta oración, este diálogo entre el fiel y la comunión de los santos. La relación con el ícono no es la de sujeto-objeto, sino de sujeto a sujeto. Es una relación co-instituida, cooperativa, no unilateral. Más que hablar, como suele decirse, de la paz que transmite el ícono, habría que hablar de la paz que permite generar el ícono, en la medida en que entendamos la paz como la concordia, com-posición, de las voluntades del cristiano y el santo representado. Podríamos decir que el ícono no está ya hecho, no es fijo, no es creado, es engendrado cada vez que se produce el verdadero encuentro. El pensamiento icónico piensa siempre desde adentro de una relación y comunión. Fuera de esta comunión no se entiende el ícono o se reduce a simple espectáculo (Marion, 2006: 151).

Es interesante observar, aunque sería mucho más extenso de tratar como se merece, el paso paulatino de la imagen icónica a la pintura con motivo religioso de la modernidad europea. La pintura heredera de los grandes maestros del Renacimiento ya no es ícono porque, más que el intento de mostrar los rasgos representativos de la persona del santo, nos muestra la especial idea o la especial reflexión e intuición que el artista ha tenido de ese santo o de esa escena bíblica. La nueva pintura posterior al Renacimiento no remite directamente al prototipo representado, sino al juicio personal del artista sobre un aspecto de la fe, a lo divino entendido como 'mero contenido de la conciencia humana' (Panofsky, 2003: 54): "La presencia de las nuevas imágenes eran tales que uno podía preguntarse si el homenaje de los fieles, en lugar de dirigirse al modelo, se dirigía sólo a

1 "Cuando usted ve una nariz, unos ojos, una frente, un mentón, y puede usted describirlos, entonces usted se vuelve hacia el otro como hacia un objeto. ¡La mejor manera de encontrar al otro es la de ni siquiera darse cuenta del color de sus ojos!" (Levinas, 2000: 71). 
ellas" (Besançon, 2003: 214). En el mismo sentido se manifiesta Belting: "En realidad, se trata de una idea que se hace visible en la obra: la idea del arte o la idea que el artista se hace de su obra" (2009: 608). Especial ejemplo de este paso es la Madonna sixtina de Rafael que mantiene las cortinas, que solían cubrir el ícono, completamente descorridas dentro de la misma pintura. La tradición del ícono mantenía estos cubiertos con cortinas durante el año y estas se descorrían en su celebración o para alguna festividad importante. De similar manera sucedía con los retablos, que no siempre se abrían. El ícono se dejaba mostrar en momentos determinados, donde se podía establecer la relación con el fiel. La comunión entre el santo y el fiel siempre conservaba los rasgos de acontecimiento histórico y era un encuentro impredecible e imprevisto, no deducible de elementos anteriores. Las cortinas siempre abiertas de la Madonna de Rafael son el paso a la contemplación de la idea religiosa del artista que se encuentra disponible a ser pensada, más allá de toda historia, acontecimiento, relación y encuentro (Nagel \& Wood, 2017: 406). Las cortinas se descorren para mostrar la idea atemporal y a-histórica de Dios que posee Rafael, más que para mostrar a la persona divina (Damisch, 1997: 40). La obra invita más al culto de la obra de arte que a la veneración del bienaventurado que viene en un momento preciso de la historia del fiel. Sin embargo, el santo sólo puede dar comienzo al encuentro si entra en la historia del hombre: "Las ideas no son íconos... las ideas no pueden recibir culto público porque este está ligado a un objeto que reside en un lugar concreto" (Belting, 2009: 646). Así es cómo entra en una historia concreta, en la composición de la relación con un hombre concreto, en un espacio y tiempo, en un acontecimiento concreto, agregaríamos.

\section{7. ÍCONO Y ENCARNACIÓN}

El antecedente histórico del ícono no es el ídolo pagano, sino la prohibición de representar a Dios en el Antiguo Testamento. Sin embargo, desde el momento en que Dios se encarna y se hace uno entre los hombres, aquella prohibición pierde su fuerza, pues hemos podido experimentar su Persona con nuestros sentidos e inteligencia. Por esto mismo, no sólo se ha entendido al ícono como una instancia de veneración, sino también como una garantía de que la encarnación efectivamente ha ocurrido. Porque la historia de Cristo es real, podemos representarla sensiblemente con los colores que conmueven nuestros ojos. Las cruentas batallas en el período iconoclasta no eran sólo una disputa estética. Los fieles no morían y no confesaban hasta la muerte la rectitud de la veneración de las imágenes, simplemente para defender sus gustos en las artes plásticas. La verdad 
es que pocos morirían por una razón tan banal. Defendiendo la pertenencia de los íconos a la tradición cristiana, los fieles confirmaban que Dios efectivamente se había hecho hombre como nosotros. Y si se había hecho hombre como nosotros, era posible representarlo tal como representamos a un hombre a quien queremos recordar y conmemorar. El fundamento del ícono es la real y leal encarnación de Cristo. Poner en duda al ícono, argumentaban los iconódulos, era poner en duda este fundamento, cediendo a doctrinas que no afirmaban la encarnación con igual convicción.

En las miniaturas de los defensores del ícono, se solía representar a Satán dañando la imagen de Dios en Adán, pero también dañando la imagen de Dios en el ícono (Grabar, 1998: 373). Los destructores de las imágenes venerables, parecieran sostener estas miniaturas, cooperan con el Maligno para que la imagen de Dios no viva en nosotros, para que no tengamos la oportunidad, frente a la tabla del ícono, de que la imagen de Dios encarnado entre en nuestras vidas. En la iconoclasia, cuyo principal argumento es la incircunscriptibilidad de la divinidad, el 'padre de la mentira' continúa su obsesión de dañar la imagen y semejanza de Dios en el hombre. La promesa de ser como dioses al comer del árbol del Bien y del Mal cae en el mismo exceso de abstracción y espiritualismo que la promesa de comprender el absoluto Dios incircunscriptible saltándonos los datos de nuestros sentidos. Tal vez el pecado mayor contra Dios es transformarlo en algo tan absoluto que no tenga ya posibilidad alguna de encontrarse con el hombre. Tratando de hacerle un gran favor a Dios, argumentando sólo su carácter absoluto, su inmensidad e infinitud, los iconoclastas han pavimentado el camino para desencarnar a Cristo, transformándolo en una idea que comprender, en unos valores morales de los cuales tomar conciencia, en un mensaje a transmitir. La abrumadora trascendencia de Dios es la causa de toda iconoclasia y, nos atreveríamos a decir, de que el cristianismo no entre en la historia de los hombres. Dañar la historicidad del cristianismo es destruirlo por completo.

No debemos, entonces, avergonzarnos de circunscribir a Dios en un cuerpo de hombre en la pintura icónica porque Él se circunscribió primero y no se avergonzó de ser hombre: "Lo divino no se avergüenza de circunscribirse en la humanidad, en el seno de una Virgen, al igual que no debemos avergonzarnos de circunscribirlo en el ícono" (Besançon, 2003: 167). Es un error la argumentación iconoclasta de que el ícono pretenda circunscribir la naturaleza divina. El ícono no circunscribe la naturaleza divina así como un retrato no circunscribe - ni limita ni reduce- la naturaleza humana. El ícono quiere representar a la Persona de Cristo, (su hipóstasis) o la de sus santos, y no tiene la pretensión de mostrar los limites de naturaleza alguna, lo que, efectivamente, es imposible. El ícono no quiere, y no puede, representar la naturaleza humana o la naturaleza divina de 
Cristo, sino los rasgos diferenciadores de su Persona, no la humanidad o divinidad, sino este hombre concreto que es Jesús de Nazaret, que es también la segunda Persona de la Trinidad que ha adquirido para siempre un cuerpo de hombre. Para siempre una existencia humana, este Jesús expresa en todo su ser el carácter propio de la persona divina del Hijo: "La humanidad de todos en la humanidad de Cristo se introduce definitivamente en la existencia celeste" (Evdokimov, 1991: 331). En la bella tarea de representar los rasgos diferenciadores de la hipóstasis de Cristo se encuentra la maestría y secreto de la iconografía: representar esa manera de ser hombre que es una manera de ser hijo. Ser hombre, por lo que vemos en Cristo, es ser hijo, es decir, dejarse generar permanentemente por el Padre. Él mismo se denominaba el Hijo del Hombre. Quien ve permanentemente en el ícono y en los santos el amor de Cristo por los hombres ve permanentemente al Padre: "Toda la particularidad personal del Hijo eterno se ha convertido en particularidad propia de la existencia, del corazón y del alma del hombre Jesús" (Schorborn, 1999: 105). La encarnación de Cristo imprimió en la naturaleza humana el amor que lo une al Padre y al Espíritu Santo, es decir, permitió que las relaciones trinitarias vivieran y se desplegaran en la historia concreta del hombre Jesús y de todos los que dan testimonio de Él. No exagera san Germán al señalar que con Cristo todo el cielo ha descendido a la tierra (Evdokimov, 1991: 15).

La belleza del ícono, como toda belleza verdadera, le habla a los sentidos y a la inteligencia, es más, podríamos decir que habla y conmueve toda la integridad del ser humano. Esto se ve claro en la iconografía donde los colores son instancia de encuentro personal e instancia para descubrir el mismo pensamiento de Cristo. El pensamiento de Cristo es puesto en las vicisitudes de la luz y las formas, tal como una teología en colores. Si tomamos en serio nuestra percepción sensible en el ícono, será muy difícil alejarla del pensar, más bien, en la medida en que es un auténtico percibir sensible es ya un pensar. $\mathrm{Y}$ viceversa, un pensar recto es un ver y un oír plenamente realizados (von Balthasar, 1985: 343-344). El pensar no es más que la continuación, culminación y coronación del percibir sensible. En el ícono al menos, no se puede separar tajantemente vista y pensamiento, no podría verse correctamente la representación del ícono sin compartir el pensamiento de Cristo. No se podría apreciar toda su significación si se lo observa como una simple pintura o como un objeto de museo. Por lo mismo, compartimos las afirmaciones de Guardini y von Baltasar en torno a la existencia de sentidos cristianos que le entregan una amplitud diferente al universo al ser percibido sensorialmente desde la fe (Guardini, 1965: 43). Dios no sólo quiso hacerse entender intelectualmente, sino que, sobre todo, quiso hacerse encontrar, constatar. Una constatación transida de pensamiento, voluntad y afecto. Dios quiso hacerse interesante para el 
hombre completo. La tradición iconográfica recuerda esta necesidad de Dios de hacerse interesante también para los sentidos humanos a los cuales nunca despreció, hacerse encontradizo para la vista, el oído y el olfato, porque sólo la carne habla a la carne (von Balthasar, 1985: 359). O como lo expresa claramente Teodoro el Estudita: "Si la contemplación según el intelecto fuera suficiente por sí misma, habría bastado que el Verbo viniera a nosotros únicamente de tal manera" (Besançon, 2003: 166).

\section{8. ÍCONO Y CLERICALISMO}

El ícono no se preocupa de pintar la naturaleza, ya sea la naturaleza del hombre como la del universo, en su estado caído y con la trizadura del pecado. La iconografía pinta más bien el triunfo del hombre, la perfección de todas las cosas por la redención efectuada por Cristo, la transfiguración del hombre y de todas las cosas por el encuentro con el Hijo de Dios, la naturaleza deificada sin la grieta ya del pecado original. El ícono es siempre imagen de esta victoria final, un atisbo de los cielos abiertos. El ícono pareciera decirnos: ¿Para qué preocuparnos de todo lo demás una vez que Cristo ha resucitado y nos ha salvado de la muerte? En el ícono no hay preocupación de lo profano ni siquiera de algunos aspectos más 'mundanos' de la vida de Jesús: su infancia, el taller de Nazaret, su encuentro con los apóstoles, las bodas de Canaá, etc. En comparación al ícono, el arte occidental posterior al Renacimiento se preocupó menos de la transfiguración y más de la naturaleza, sin dejar nada afuera (retratos, bodegones, paisajes, escenas históricas y bíblicas, escenas cotidianas, etc.). Buscó menos la naturaleza deificada que la respetuosa mirada por el carácter natural -nos atreveríamos a decir 'laico'- del hombre y la creación, pero, porque buscó siempre la naturaleza con fidelidad, por eso mismo, en ocasiones, se encontró con la Gracia. ¿No vemos cooperación divina en algunas obras de Giotto, Delacroix, Rembrandt, Millet, Caravaggio? Esto no las convierte en íconos, pero sí puede inclinarnos a pensar que, respetando y estando atento a la configuración de la experiencia humana, a veces nos topamos con la Gracia. Mal que mal ella no viene cuando se nos antoja, sino cuando lo estima conveniente (Jn 3, 8).

Sin embargo, se hace cierta defensa clerical del ícono, a nuestro modo de ver, que considera que el 'naturalismo' o 'verismo visual' del arte occidental posterior al Renacimiento implica rebajar al hombre: "El hombre sigue siendo el tema principal de la imagen pero en su estado actual, no transfigurado...queda rebajado al nivel del resto de la creación, perdiendo la soberanía de la misma. Se rompe la jerarquía del ser" (Uspenski, 2013: 
$374)^{2}$. Creemos, al contrario, que pintar al hombre en su estado natural no es necesariamente rebajarlo, porque en su estado natural ya posee un valor que la gracia transfiguradora podría perfeccionar, pero que no pretende destruir ni despreciar. La naturaleza humana está herida por el pecado original, pero no está completamente corrupta. Sin embargo, tomándose de esto, esta visión da por hecho que el fundamento teológico del ícono, cuya importancia y hondura nadie niega, de por sí le asegura la superioridad artística por sobre otra forma de arte. A partir de esto, muchos intentar pasar al argumento de la superioridad de la Iglesia ortodoxa por sobre la católica romana: "De ahí que tanto la teología como la espiritualidad y el arte occidentales se concentran en la humanidad del Señor...su carne deificada desaparece tras su 'aspecto de siervo"' (Uspenski, 2013: 469). El ícono siempre buscó pintar la naturaleza ya victoriosa y transfigurada. Para ello, apoyado por la tradición, pidió para sus obras la presencia de la Gracia. No negamos que lo haya conseguido, muy por el contrario, pero pensamos que algunos de sus defensores, brillantes en muchos sentidos (tales como Uspenski, Florenski, Trubeckoj, Evdokimov), han creído tener la seguridad completa de que la iconografía era ya de por sí mejor en todos los sentidos porque sus temas versaban en el reino de Dios. Sostenemos que tales estudiosos caen, al menos en este punto, en el clericalismo de creer que, por surgir al amparo de la Iglesia, los íconos son el mejor y el único camino que debe seguir la imagen cristiana ${ }^{3}$. Haciéndole, de paso, un mal favor al ícono y a la Iglesia ortodoxa que pretenden defender. Seguir estos criterios termina transformando el cristianismo en un sistema ideológico con pretensiones de uniformar la sociedad, la moral, el arte, la cultura toda bajo la severa vigilancia de una creencia unánime. Sin perder la vocación universal para propagar la 'buena nueva', el cristiano no puede

2 Uno de estos autores es Trubetzkoj, que llega a sentir nauseas ante un Rubens: "La náusea que sentí al ver las bacanales de Rubens me hizo comprender de inmediato la propiedad de los íconos en la que estaba pensando. La bacanal es la forma extrema de la vida que el ícono rechaza. La carne repleta y temblorosa que se deleita en sí misma, se atiborra de carne y tiene que matar para atiborrarse, todo eso es lo que rechazan los dedos que nos bendicen. Mientras nos seduzcan los deleites de la carne, el ícono no nos hablará" (1989: 22-23).

3 Por ello se espantan de las influencias occidentales sobre la pintura oriental o, más precisamente, sobre la tradición iconográfica rusa desde el siglo XIX en adelante. En ocasiones son capaces de enviar a la hoguera toda la tradición del arte occidental de los últimos siglos, como en este párrafo muy destemplado de Florenski: "Las primeras y más sutiles evaporaciones del naturalismo, del humanismo y de la Reforma proceden de aquella inocente 'ovejita de Dios', Francisco de Asís, quien fue canonizado para inmunizarse de él, únicamente porque no se dieron la prisa suficiente en mandarlo a la hoguera. Mientras tanto, la primera manifestación del franciscanismo en el arte fue el giottismo" (2005: 45). 
caer en el desprecio de lo 'no cristianizado' como si fuera de menor valor. Gracias al valor de la naturaleza y de las virtudes naturales del hombre, la gracia puede entrar en la historia humana. Despreciar lo 'no cristiano' de por sí, sin demasiado análisis, puede terminar siendo un obstáculo para la Gracia divina, ya que le quitaríamos a su socio-cooperador sin el cual no puede intervenir en nuestra vida. Las afirmaciones de estos autores, en el sentido mencionado, nos parece que son motivadas también por la multiplicación vertiginosa de imágenes y el tormentoso surgimiento de visiones de mundo en el arte contemporáneo que muestran un destino muy alejado de la unidad y de respeto a una sola autoridad y norma. Este panorama de fecundidad, desorden y vértigo en el arte actual puede motivar que dirijamos nuestra mirada hacia la unidad que tuvo el ícono como forma de arte, al menos antes del Renacimiento, que caminaba coherente con la vida privada, la vida social, la cultura y nuestras esperanzas últimas. Frente a la disolución de las imágenes en nuestro presente artístico, surge la añoranza por este arte antiguo que entregaba consenso y paz a la vida del creyente y del ciudadano (Belting, 2009: 546). Sin embargo, creemos que la herencia del ícono en el arte es mucho más significativa que este simple arcaísmo.

Llama la atención que finalmente esta visión clerical y la iconoclasia del arte abstracto contemporáneo (Kandinski, Malevich, Mondrian, por ejemplo) se encuentren en este punto: sólo lo divino es digno de ser pintado (Golding, 2003: 26). Con sentidos muy distintos, por cierto, pero ambos quieren esquivar y 'saltarse' la naturaleza. Los clericales quieren hacerlo con el argumento de que es una naturaleza no transfigurada y 'sierva' del pecado original, el arte abstracto más bien empujado por la rebeldía de no repetir las imágenes de la naturaleza para elevarse al reino del Espíritu y de lo Absoluto más allá de las formas y las figuras ya hechas (Golding, 2003: 41-42). El punto en común de ambos, no obstante, es un desprecio de la naturaleza en función de buscar para el arte un objeto superior que coincide con lo divino o espiritual.

La línea argumental del arte abstracto nos lleva finalmente a una modulación estética del gnosticismo (Voegelin, 1973: 70; 1990: 24-25; Schorborn, 1999: 67; Besançcon, 2003: 414-419). No creemos que las posturas clericales mencionadas lleguen a ese nivel, porque todavía en el ícono está el hombre en toda su encarnación. Sin embargo, con esto indicamos el peligro al que puede llevar esta consideración del ícono que reduce la representación sólo a la naturaleza transfigurada, olvidándose y relegando a un lugar muy secundario la carne e historia en la que quiso vivir Cristo también. 


\section{CONCLUSIONES}

Después de llevar a cabo esta revisión en torno a la tradición del ícono, creemos que su herencia en el arte se puede sintetizar en estos cinco puntos:

1.- El ícono puede describir la transfiguración del hombre en su encuentro con Cristo solo porque primero tiene la fuerte convicción del valor de la condición de hombre. Solamente puede mostrar al hombre redimido en cuanto todavía logra valorar al hombre en su espíritu corporizado, es decir, en su situación actual. No se puede representar la santidad si no se cree primero en la humanidad. Antes de ser santo se debe ser primero un hombre. Tras el ícono, creemos, está la tradición de los padres de la Iglesia que sostienen que la gracia perfecciona la naturaleza, pero no la destruye.

2.- Emergiendo del punto anterior, indicamos que el ícono puede heredar al futuro arte cristiano, en particular, el respeto por la verdad y belleza de la naturaleza del universo y del hombre. El arte cristiano no será cristiano por dar por ganada la gracia divina: el arte cristiano será un fiel y respetuoso observador de la realidad. Si se representa la experiencia humana con fidelidad, la gracia divina nunca andará muy lejos. El signo del arte cristiano no es la presencia de motivos religiosos, sino la fidelidad a la encarnación. Recurrimos nuevamente a Péguy: "No basta rebajar lo temporal para elevarse en la categoría de lo eterno. No basta rebajar la naturaleza para elevarse en la categoría de la gracia. No basta rebajar el mundo para subir en la categoría de Dios" (Péguy, 1946: 156). Lo peor que se puede hacer con Cristo es transformarlo en una mera idea, en un absoluto, en un concepto sin carne.

3.- Un rasgo que ha heredado el ícono al arte universal es la posibilidad de concebir la generación de imágenes como instancia de encuentro. En varios sentidos podemos afirmar esto. En primer lugar, el ícono siempre se pensó como una obra colectiva, como obra de una tradición, en la cual el pintor se percibía como un obrero más. En cierta medida era el trabajo de reflexión en torno a las cuestiones fundamentales de la existencia no sólo de una mente brillante, sino de muchas vidas y destinos. Este fruto heredado, creemos, podría ser experimentado en mayor medida en el arte actual y en el arte por venir. En segundo lugar, el mismo ícono, en cuanto remite a una persona, a un prototipo, es instancia de encuentro. En efecto, sobre todo en nuestra época, esto puede ser provechoso en la medida que nos encontramos rodeados de imágenes que no abren a nada, que no remiten a ningún prototipo, que son imágenes y originales al mismo tiempo (Belting, 2009: 639; Marion, 2006: 92). 
4.- Destacamos también la imagen del ícono como una manifestación del hecho poco desarrollado filosóficamente de la percepción y el pensamiento comunional. En el ícono se pinta la relación del hombre con Cristo, su amistad con el redentor y la trasformación de su vida en base a esta amistad. El hombre es transfigurado por las relaciones que llenan de significatividad su vida y según ellas percibe y piensa. El hombre no percibe en soledad, sino en relación. Lo que llamamos ser es principalmente un acontecer-imprevisto, no deducible de elementos anteriores- que el hombre percibe en relación. El ser no es un esse, sino más bien un adesse, que acontece en una primigenia relación que nos abre al mundo, es co-adesse (Marcel, 1987: 70). Esta valentía que ha tenido el ícono de representar no sólo una perspectiva, sino una comunión; no sólo un punto de vista, sino un encuentro; no sólo un objeto, sino una presencia, es un legado invaluable para todo el presente y futuro del arte.

5.- Nos atrevemos a concluir que el cristianismo no sólo abre las posibilidades para la creación de imágenes, sino que, en su esencia, el cristianismo está ligado a las imágenes, podríamos decir, incluso, que necesita de ellas. El mismo san Pablo llama a Cristo la imagen, eikon, ícono de Dios (2 Corintios 4, 4). El mismo Cristo ha recalcado su carácter de ícono, es decir, de tipo que remite a un prototipo que lo ha engendrado: "El que me ve a mí ve al Padre" (Jn 14,9). Dios mismo ha querido dejar su imagen en el hombre, imagen y semejanza que vino a restituir su Hijo, su imagen increada.

\section{REFERENCIAS}

Belting, H. (2009). Imagen y culto. Una bistoria de la imagen anterior a la edad del arte. (C. Diéz y J. Espino Trad.). Madrid: Akal.

Berenson, B. (1944). Los pintores italianos del Renacimiento. (Amelia Bertarini, Trad.). Buenos Aires: El Ateneo.

Bergson, H. (1969). La pensée et le mouvant. Essais et conférences. Paris: Les Presses universitaires de France.

Besançon, A. (2003). La imagen probibida. Una historia intelectual de la iconoclasia. (E. Castejón, Trad.). Madrid: Siruela.

Beuchot, M. (1999). Las caras del símbolo: el ícono y el ídolo. Madrid: Caparrós editores.

Brown, H. (1998). La nueva filosofía de la ciencia. (G. Solana, Trad.). Madrid: Tecnos. Buber, M. (2013). Yo y tú. Buenos Aires: Nueva visión.

Damisch, H. (1997). El origen de la perspectiva. (Federico Zaragoza, Trad.). Madrid: Alianza.

Evdokimov, P. (1991). El arte del icono. Teología de la belleza. (L. García, Trad.) Madrid: Publicaciones claretianas. 
Florenski, P. (2016). El iconostasio. Una teoría de la estética. (N. Timoshenko, Trad.). Salamanca: Sígueme.

Florenski, P. (2005). La perspectiva invertida. (X. Egórova, Trad.). Madrid: Siruela.

Golding, J. (2003). Caminos a lo Absoluto. (J. Fondebrider, Trad.). Madrid: FCE.

Gombrich, E.H. (1997). La historia del arte. (R. Santos Toroella, Trad.). Madrid: Debate.

Gombrich, E. H. (2014). Arte e Ilusión. Estudio sobre la Psicología de la representación pictórica. (G. Ferrater, Trad.). Londres: Phaidon.

Grabar, A. (1998). La iconoclastia bizantina. Dossier arqueológico. (A. López, Trad.). Madrid: Akal.

Guardini, R. (1960). Imagen de culto e imagen de devoción. Sobre la esencia de la obra de arte. (J. M. Valverde, Trad.) Madrid: Ediciones Guadarrama.

Guardini, R. (1965). Los sentidos y el conocimiento religioso. (A. Sánchez y J. M. Valverde, Trad.). Madrid: Ediciones cristiandad.

Juan Pablo II (1999). Carta de Juan Pablo II a los artistas. Disponible en http://w2.vatican.va/content/john-paul-ii/es/letters/1999/docu-

ments/hf_jp-ii_let_23041999_artists.html; consultado el 11 de junio de 2018.

Levinas, E. (2000). Ética e infinito. (J. M. Ayuso, Trad.). Madrid: Machado libros.

Levinas, E. (2002). Totalidad e infinito. Ensayo sobre la exterioridad. (D. Guillot, Trad.). Salamanca: Sígueme.

Marcel, G. (1987). Aproximación al misterio del ser. (J. L. Cañas, Trad.). Madrid: Encuentro.

Marion, J. L. (2006). El cruce de lo visible. (J. Bassas y J. Masó, Trad.). Castellón: Ellago Ediciones.

Nagel, A. \& Wood, C. S. (2017). Renacimiento anacronista. (F. López Martín, Trad.). Madrid: Akal.

Nancy, J. L. (2012). La mirada del retrato. (I. Agoff, Trad.). Buenos Aires: Amorrortu editores.

Panofsky, E. (2003). La perspectiva como forma simbólica. (V. Careaga, Trad.). Barcelona: Tusquets.

Péguy, Ch. (1946). Nota conjunta sobre Descartes y la filosofía cartesiana. (M. Brugnoli, Trad.). Buenos Aires: Emecé editores.

Péguy, Ch. (1992). Euvres en prose complètes (vol. III). Paris: Gallimard.

Scheler, M. (2000). Schriften aus dem Nachlass, I. Zur Ethik und Erkenntnistheorie. Bonn: Bouvier Verlag.

Schorborn, Ch. (1999). El icono de Cristo. Una introducción teológica. (A. Bellilla, Trad.). Madrid: Encuentro.

Trubeckoj, E. (1989). Contemplazione nel colore. Tre studi sull' icona russa. (P. Cazzola, Trad.). Milano: La casa di Matriona.

Uspenski, L. (2013). Teología del ícono. (R. J. Sánchez, Trad.). Salamanca: Sígueme. Voegelin, E. (1973). Ciencia, politica y gnosticismo. (E. Prieto, Trad.). Madrid: Rialp. Von Balthasar, H. U. (1985). Gloria. Una estética teológica. (E. Saura, Trad.). Madrid: Encuentro. 
Sumario: Introducción; 1. Ícono e ídolo; 2. El iconógrafo y sus fuentes; 3. El ícono como trabajo compuesto; 4. Ícono y transfiguración; 5. Ícono y tradición; 6. Ícono y perspectiva; 7. Ícono y encarnación; 8. Ícono y clericalismo; Conclusiones; Referencias. 